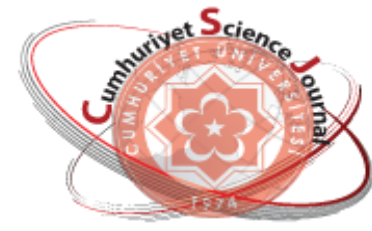

e-ISSN: $2587-246 X$

ISSN: 2587-2680

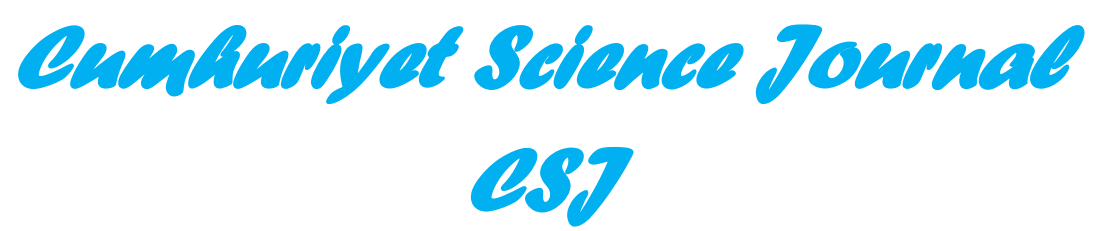

Cumhuriyet Sci. J., Vol.40-3(2019) 768-775

\title{
Effects of Calcined Phosphogypsum on the Geotechnical Parameters of Fine- Grained Soils
}

\author{
Ahmet ŞENOL ${ }^{1, *}$ \\ ${ }^{1}$ Cumhuriyet University, Faculty of Engineering Department Civil Engineering, 58140 Sivas
}

Received: 07.02.2019; Accepted: 17.09.2019

http://dx.doi.org/10.17776/csj.523979

\begin{abstract}
In this article, the using of waste materials has been studied such as phosphogypsum in the alteration of fine-grained soils in order to upgrade the geotechnical properties as a construction material. Standard Proctor test, unconfined compressive strength tests and California bearing ratio were carried out on Calcined Phosphogypsum (CPG) stabilized soil samples. It was determined that the phosphogypsum with additives calcined at the low temperature $150{ }^{\circ} \mathrm{C}$. Treatment with $\mathrm{CPG}$ generally reduces the maximum dry density but CPG increase the optimum moisture content. Compressive strength, California bearing ratio were performed to investigate effects of additive mixtures of stabilized and natural soil specimen. The empirical results show that stabilized samples with CPG additive mixtures have high durability as compared to unstabilized samples. These contribution blends have also improved the dynamic behaviors of the soil samples. As a result, we conclude that CPG additive mixtures can be completely used as an additive material to strength of granular soils in highway constructions and embankment applications. The experiment results understood that the stabilized fine-grained soil specimens containing CPG show high resistance to the CBR and unconfined compressive strengths as compared to natural fine-grained soil samples.
\end{abstract}

Keywords: Soil stabilization, waste materials, phosphogypsum, fine-grained soils.

\section{İnce Taneli Zeminlerin Geoteknik Özelliklerinde Kalsine Edilmiş Fosfojips'in Etkisi}

Özet. Bu çalışma, bir yapı malzemesi olarak ince taneli zeminlerin geoteknik özelliklerini yükseltmek için fosfojips gibi atık maddelerin kullanımını değerlendirmektedir. Kalsine Fosfojips (CPG) ile stabilize edilen zemin numuneleri üzerinde, standart proctor deneyi, Kaliforniya taşıma gücü ve serbest basınç ve optmum su muhevası deneyleri yapılmıştır. Gübre fabrikası atığı olan fosfojips $150{ }^{\circ} \mathrm{C}$ gibi düşük sıcaklıkta kalsine edilmiştir. Kalsine edilmiş fosfojips (CPG) katılan ince taneli zeminlerin maksimum kuru yoğunluğu azalmıştır, ancak optimum su muhtevası değerleri artmıştır. Serbest basınç mukavemetinin, California taşıma gücü oranının, doğal ve stabilize zemin örnekleri üzerindeki etkileri araştırılmıştır. Deney sonuçları, stabilize edilmemiş numunelere kıyasla CPG katkılı karışımların daha yüksek dayanıklılığa sahip olduğunu göstermektedir. Sonuç olarak, CPG katkılı karışımların, yol inşaatları ve hafriyat dolgu uygulamaları için ince taneli zeminlerin dış etkilere karşı mukavemetinde başarılı bir şekilde kullanılabilineceği sonucuna varılmıştır. Test sonuçları, CPG içeren stabilize ince taneli zemin numunelerinin, doğal ince taneli zemin numunelerine kıyasla daha yüksek CBR direnci ve serbest basınç mukavemeti sergilediğini göstermektedir.

Anahtar Kelimeler: Zemin stabilizasyonu, atık malzemeler, fosfojips, ince taneli zeminler. 


\section{INTRODUCTION}

Chemical improvement is the variety of the properties of a locally existing soil to improve its mechanical capacity. The lime stabilization and cement stabilization are two most frequently used chemical improvement methods [1]. To further improve the properties of stabilized soil, phosphogypsum can be added to the soil as an additive. In this study, phosphogypsum, an industrial waste, has been used as a chemical stabilization ingredient to improve the mechanical properties of chosen soils. Phosphogypsum (PG) is industrial waste of products in phosphoric fertilizer factories. Roundly 3500 tons per day of PG are produced every year in BandirmaBAGFAŞ plant of Turkey; these wastes are tried to be made harmless by various ways in landfills, rivers and waste ponds.

Phosphogypsum consists of some impurities such as $\mathrm{P}_{2} \mathrm{O}_{5}, \mathrm{~F}^{-}$, essentially of calcium sulfate and organic substances. The use of phosphosypsum as construction material is restricted. The reason for this is the presence of purity in it. The gypsum and cement industries currently use only a small proportion of this by-product as a retarder for cement and for the construction of bricks and gypsum plaster [1-8]. Phosphogypses were reused with some achievement in the road substructures and cylinder compressed concrete [9-10]. Phosphogypsum can be improved by fly ash with thermal power plant waste that other industrial waste and Portland cement for possible use in soil improvement. Phosphophosum mixed with cement has long been studied for about ten years $[11,12]$. Phosphogypsum is not enough for road infrastructure or embankment construction lonely. Blends prepared with fly ash, phosphogypsum, and Portland cement provide slightly higher geotechnical values maximum dry unit weight and OMC values for improved phosphogypsum mixtures, in comparison with unimproved phosphogypsum mixtures. Most of these studies suggested that cement with $\mathrm{C}_{3} \mathrm{~A}$ content less than $7 \%$ can be used with phosphogypsum [13]. The planned properties of soil-cement mixture and soil type describes cement content requirements. The amount of clay in the soil is decisive for stabilization in generally. Some studies suggest that the amount of cement content can be chosen between $5 \%-15 \%$ by clay. [14,15]. Researchers are also advised to prepare almost too close to the optimum water content and maximum dry unit weight values when preparing mixtures containing phosphogypsum (PG). [16,17].

Many methods to change the geotechnical properties of fine-grained soils have been proposed to date. These methods can be expressed as stabilization by chemical ejection, wetting, other soil displacement, compression control, moisture control, additional load loading and thermal methods [18-20]. In particular, new studies are carried out to reduce swelling behavior and permeability. These studies ultimately increase the Strength properties. [21-23]. Many researches have studied natural materials and fabricated products such as geofiber to change the fine-grained soils.

The main purpose of this study is to investigate the suitability of phosphogypsum calcined at the low temperature $150{ }^{\circ} \mathrm{C}$ to increase on the geotechnical properties of fine-grained soils as a stabilization material. Stabilized and natural finegrained soil samples were tested in laboratory conditions to obtain better results.

\section{MATERIALS AND METHODS}

\subsection{Fine-Grained Soil}

The fine-grained soil has been supplied from the basalt quarry crusher plant deposits of MesudiyeÇatalkaya, Ordu, Northeast of Turkey (Fig.1). The material used in experimental studies remain within the boundaries of the base material granulometry determined by the General Directorate of Highways of Turkey. X-ray diffraction (XRD) pattern of the fine-grained soil and the grain-size distribution are given in Figs. 2 and 3. Meanwhile, its engineering and index properties are summarized in Table 1. 


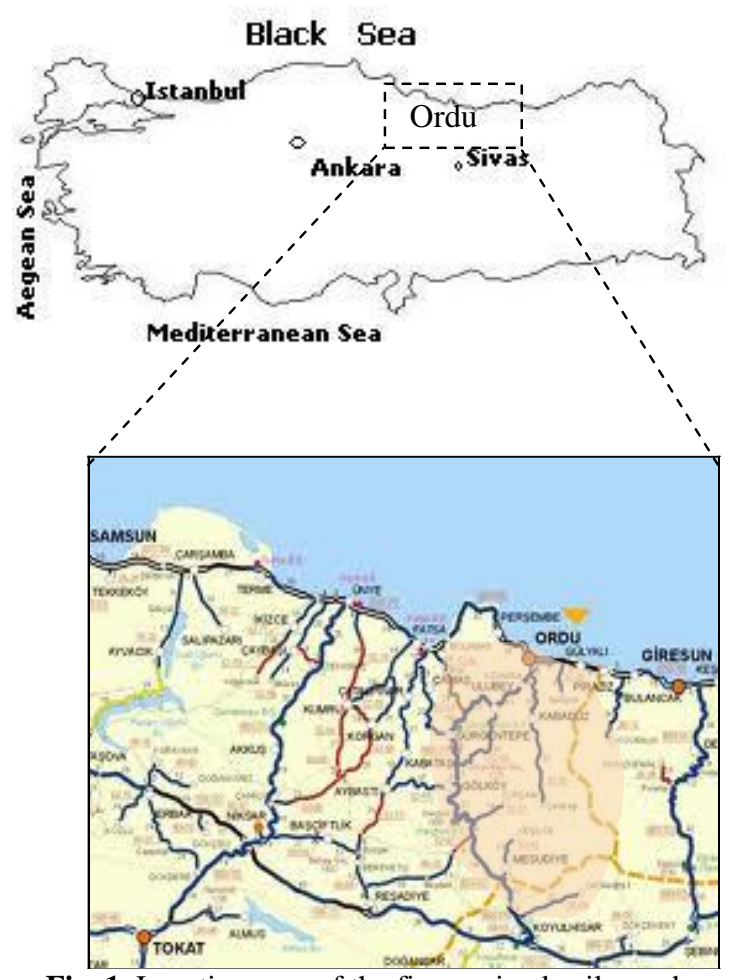

Fig. 1. Location map of the fine-grained soils used.

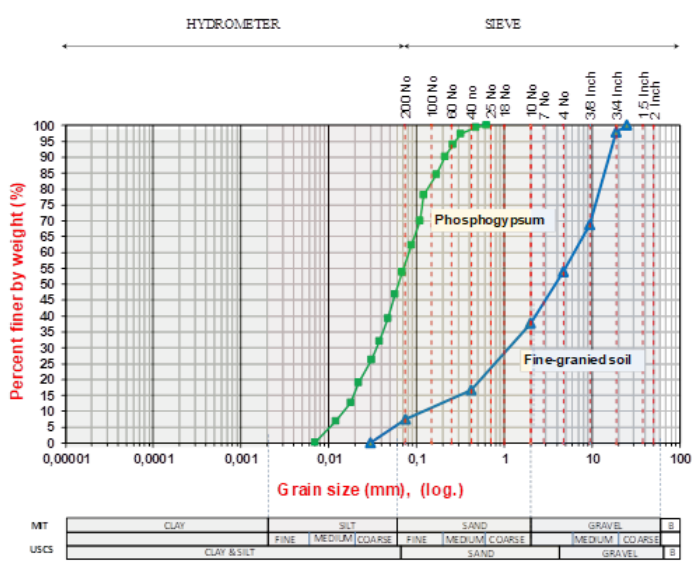

Fig. 2. The grain-size distributions of fine-grained soil and phosphogypsum.

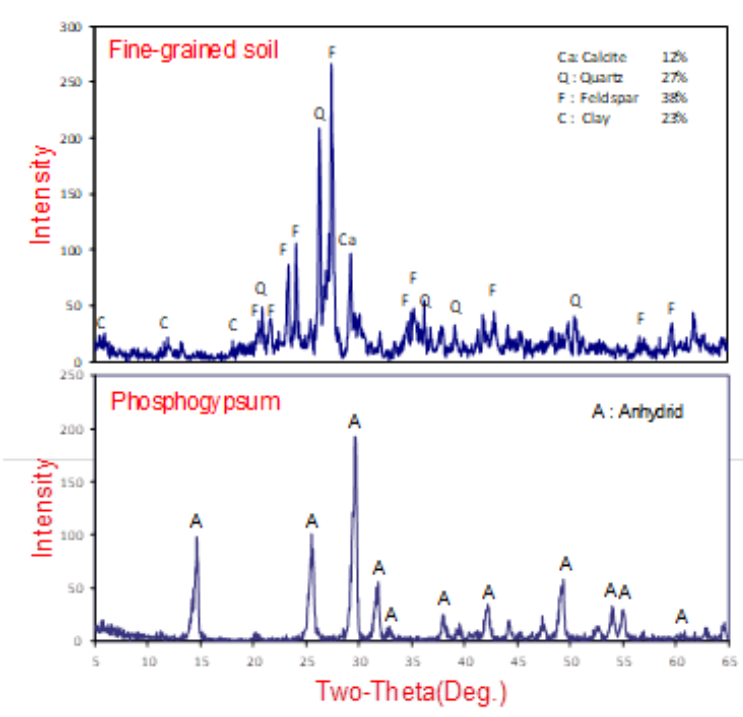

Fig. 3 X-ray diffraction (XRD) pattern of the fine-grained soil and the phosphogypsum

Table 1 Engineering properties of Phosphogypsum and finegrained soil.

\begin{tabular}{rll}
\hline \multicolumn{1}{c}{ Property } & Fine-grained soil & Phosphogypsum \\
\hline Density & & \\
Density, $(\mathrm{Mg} / \mathrm{m} 3)$ & 2.649 & 2.39 \\
Grain-size & & \\
Gravel $(>2000 \mu \mathrm{m}), \%$ & 60 & -- \\
Sand $(2000-75 \mu \mathrm{m}), \%$ & 35 & 55 \\
Silt $(2-75 \mu \mathrm{m}), \%$ & 5 & 45 \\
Clay $(<2 \mu \mathrm{m}), \%$ & -- & -- \\
\hline
\end{tabular}

\subsection{Phosphogypsum}

Bandırma-Turkey Fertilizer Plant which PG used in the research was brought here, obtains PG as a by-product in the process of producing phosphoric acid production by phosphate rock. The chemical compositions of waste phosphogypsum is seen in Table 2. Important component of PG is calcium sulfate and, consequently, PG (pH less than 3) exhibits acidic properties. The relative density of PG is 2.87 , the optimum water content is $12-13 \%$ and the maximum dry density is $14.53 \mathrm{kN} / \mathrm{m}^{3}$, according to the standard Proctor test. The grain size distribution range is $0.5-1.0 \mathrm{~mm}$. PG can be classified as a silty soil also seen from the Fig 1., a ML (USCS) or A-4 (AASHTO) soil, with almost no plasticity. PG determined by The Nuclear Research and Training Center in Çekmece/Turkey, known as ÇNAEM are ${ }^{226} \mathrm{Ra}$ : $22 \mathrm{~Bq} \mathrm{~kg}^{-1},{ }^{238} \mathrm{U}: 9.0 \mathrm{~Bq} \mathrm{~kg}{ }^{-1},{ }^{232} \mathrm{Th}: 1.0 \mathrm{~Bq} \mathrm{~kg}{ }^{-1}$ and ${ }^{40} \mathrm{~K}: 11 \mathrm{~Bq} \mathrm{~kg}^{-1}$. As a result of the measures taken by Bagfas fertilizer plants, phosphogypsum 
has been classified as a weak radioactive substance [24].

The PG was stored outdoors fields, and the convenient amount of PG was air-dried and calcined at low temperature. The required amount of calcined phosphogypsum (CPG) measured depending on weight of waterless soil and incorporated to the soil. The ingredients (soil +
CPG) were first added and mixed in dry condition for $3 \mathrm{~min}$, and then to a certain extent water was added and the mixer was stirred for 2 minutes. The mixture was put into the mold and compressed. The amount of water added to the mixture is determined as the optimum water content.

Table 2 The chemical compositions of waste phosphogypsum

\begin{tabular}{ccccccccccc}
\hline $\begin{array}{c}\text { Chemical } \\
\text { parameters }\end{array}$ & $\mathrm{SiO}_{2}$ & $\mathrm{Al}_{2} \mathrm{O}_{3}$ & $\mathrm{Fe}_{2} \mathrm{O}_{3}$ & $\mathrm{CaO}$ & $\mathrm{SO}_{3}$ & $\mathrm{Na}_{2} \mathrm{O}$ & $\mathrm{P}_{2} \mathrm{O}_{5}$ & $\mathrm{~F}$ & $\mathrm{CaO}_{\text {free }}$ & $\begin{array}{c}\text { Loss on } \\
\text { ignition }\end{array}$ \\
$\mathbf{P G}$ & 3.44 & 0.88 & 0.32 & 32.04 & 44.67 & 0.13 & 0.50 & 0.79 & 0.81 & 21.06 \\
\hline
\end{tabular}

\subsection{Experimental Study}

Soil sample can be classified as an A-1,A-3 soil according to the the AASHTO soil classification system and according to the Unified Soil Classification System SP-SM type.

The mixtures were composed of different percentage of calcined phosphogypsum by holding the optimum water content. The mixture proportions of the bonding agents are given in Table 3. Phosphogypsum was used as unworked and calcined materials for making the adhesive agent. A appropriate amount of phosphogypsum was air dried and sieved through a $4.75 \mathrm{~mm}$ sieve before using. To create calcined gypsum, phosphogypsum was heated in an electric oven at $150{ }^{\circ} \mathrm{C}$ for 6 hours. The calcined material was desiccated in a closed container to room temperature to avoid any contamination.

Maximum dry density and OMC of all mixtures were obtained by SPT with respect to AASHTO T - 99 and ASTM. When the compression process was in progress, the soil determined by the amount of water was placed in a mold of standard sizes in five layers, and compacted by 56 blows of rammer dropped from a distance of $457 \mathrm{~mm}$ at each layer, subjecting the soil to total compactive effort.

The unconfined compression (UC) tests were implemented according to ASTM 266 and unconfined compression strength values (qu) were determined. Samples with a $30 \mathrm{~cm}$ length and 15 $\mathrm{cm}$ diameter were prepared. The samples were placed in a great desiccator (humidification vessel) to prevent from drying while waiting a turn at the compression machine. Six samples were prepared for each ratio and tested at a deformation rate $0.5 \mathrm{~mm} / \mathrm{min}$.

The homogeneous soil blend was created by adding the required amount of stabilizer. The required water determined is poured into soil mixtures. The species were molded at maximum unit weight and OMC in accordance with ASTM D1557. Geotechnical tests as SPT and unconfined compressive strength (qu) tests were applied on soil samples prepared with stabilizer addition at variable percentages in order to examine their influence. Tables 3. Presents Compaction features and the definition of soil mixtures. Each soil samples used in the unconfined compressive strength test was statically compacted in the cylindrical mold $(15 \mathrm{~cm}$ in diameter and $30 \mathrm{~cm}$ high) at the optimum water content and maximum dry density. For curing, the samples were closely covered and placed in any box. Ambient temperature fixed to $21^{\circ} \mathrm{C}$. The species cured for 7 days and after curing unconfined compressive strength test was conducted.

\subsection{California bearing ratio tests}

CBR method is the most common method for evaluating the comparative resistance of soils in road construction. California bearing ratio (CBR) tests were performed using a cylindrical test mould kit on samples compacted in three layers at maximum dry unit weight and the OMC determined by conducting standard Proctor tests. 
The tests were performed following AASHTO T193. According to AASHTO T193-63 and ASTM D1883-73, the soaking period for CBR samples for normal soil is $96 \mathrm{~h}$ or 4 days.

The CBR specimens prepared with different proportions of CPG to soil at its optimum water content were compacted and then soaked in water. The results of CBR tests obtained are tabulated in Table 3. For evaluating of efficiency of CPG improvement on CBR's results and also swelling potential of soil the soaked and unsoaked CBR tests are conducted on natural soil samples at first and the amount of swelling is obtained about 1 percent. Then specimens are prepared with different mixtures of CPG. These samples are exposed to a temperature of 23 degrees Celsius for 28 days while maintaining the same humidity. After that unsoaked CBR results of samples were calculated. After that, the prepared samples were immersed in water for 96 hours and reading of swelling is controlled. Then saturated CBR tests results were calculated. The results are showed in Table 3and Fig 6. It appears that the addition of $20 \%$ CPG gives the maximum percentage increase in CBR value (ratio of obtained CBR value/highest $\mathrm{CBR}$ value) after curing for 96 hours; see Fig. 5 (a). The CBR amounts of prepared specimens with different CPG percentage $(5,10,15$ and 20 percent) show that improving soil with CPG is most suitable.

Table 3. Detail of Soil-CPG Mixtures for Tests Conducted

\begin{tabular}{|c|c|c|c|c|c|c|c|c|}
\hline & Combination & $\begin{array}{c}\text { MDU } \\
\text { W } \\
\left(\mathrm{kg} / \mathbf{m}^{3}\right)\end{array}$ & $\begin{array}{c}\text { OWC } \\
(\%)\end{array}$ & $\begin{array}{c}\text { CBR }_{\text {averag }} \\
\text { e }\end{array}$ & $\begin{array}{l}\text { CBR }_{\text {rate }} \\
\text { of increase }\end{array}$ & $\begin{array}{c}\text { Percent } \\
\text { swell } \\
\text { CBR }(\%) \\
\end{array}$ & $\begin{array}{l}\text { Max. } \\
\text { stress } \\
(\mathbf{k P a}) \\
\end{array}$ & $\begin{array}{c}\text { Axial } \\
\text { strain } \\
(\%)\end{array}$ \\
\hline SOIL & SOIL & 2225 & 4.3 & 184.53 & 1,0 & 3.05 & 637.43 & 13.800 \\
\hline SOPG5 & SOIL+ PHOSPHOGYPSUM $5 \%$ & 2220 & 5.3 & 209.04 & 1,1 & 2.67 & 906.13 & 12.933 \\
\hline SOPG10 & SOIL+ PHOSPHOGYPSUM $10 \%$ & 2151 & 5.5 & 218.86 & 1,2 & 2.56 & 1061.08 & 10.467 \\
\hline SOPG15 & SOIL+ PHOSPHOGYPSUM $15 \%$ & 2140 & 7.0 & 229.58 & 1,2 & 2.43 & 1211.12 & 9.733 \\
\hline SOPG20 & SOIL+ PHOSPHOGYPSUM $20 \%$ & 2059 & 7.64 & 239.41 & 1,3 & 2.35 & 1379.80 & 8.600 \\
\hline
\end{tabular}

\section{RESULT AND DISCUSSION}

3.1. Analysis of compaction parameters in mixtures

Figs. 4. shows the effects of bonding agent mixtures on the $\mathrm{OMC}$ and the maximum dry densities. The results presents that the supplement of bonding agent mixtures revealed an increase in $\mathrm{OMC}$ and a reduction in maximum dry density. The high dry unit weights and the low OMC occur in unimproved samples, while the low dry unit weights and the high OMC occur in improved samples with 20\% CPG bonding agent mixtures. The reason why increased in OMC is an increase in the total particle surface area of the improved samples due to the addition of finer materials. That's why, the OMC increased in the improved samples. Depending upon an increase in OMC, the maximum dry unit weights decreased in the improved specimens gradually. It was found that the OMC ranged from 4 to $8 \%$ for fine grained soil and the maximum dry densities ranged from 2.2 to 2.05 in $\mathrm{Mg} / \mathrm{m}^{3}$ for fine grained Soil.

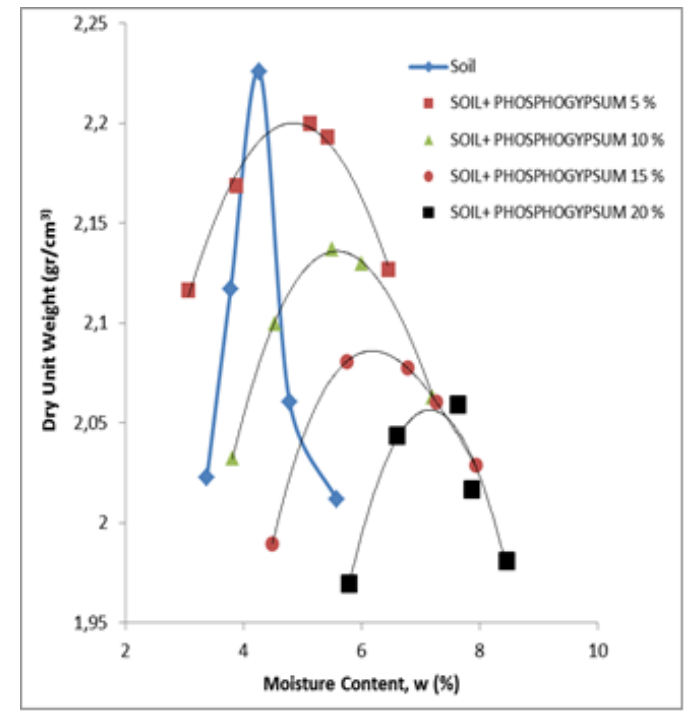

Fig. 4. Effects of CPG on the dry unit weight and moisture content. 
3.2. Analysis of compressive strength in mixtures

Fig. 5 presents the effects of bonding agent mixtures on the compressive strength. It is observed that the compressive strength results increase by the addition of bonding agent mixtures in the improved samples. The CPG particles stabilize the soil matrix at the interfaces with the soil textures, resulting in a denser improved soil sample. Unconfined compressive strengths of unimproved soils were in all situations lower than improved soils. There is significant benefit strength with addition of CPG. The benefit in unconfined compressive strength is dependent on the CPG content. A high increase in unconfined compressive strength take placed with $20 \%$ of CPG content for soil.

\subsection{Analysis of $\mathrm{CBR}$ in additive mixtures}

The CBR test was performed to investigate the behavior of samples stabilized with additives. These tests were carried out in the Modified Proctor mold by adding the additive and adding the additive. These tests were repeated on day 28 . The effects of additive mixtures on CBR are given in Figure 6. With increasing amounts of CPG additive, it has been shown that CBR values are increased and this is achieved in all mixtures. Depending on the amount of additive, the compressive strength and CBR were found to be increased. It is seen from the results of natural

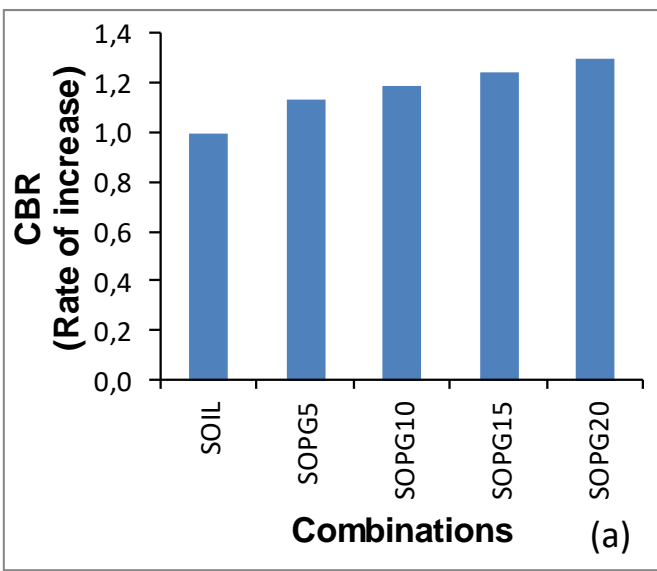

samples and stabilized samples that there is a linear relationship between the compressive strength and CBR values.
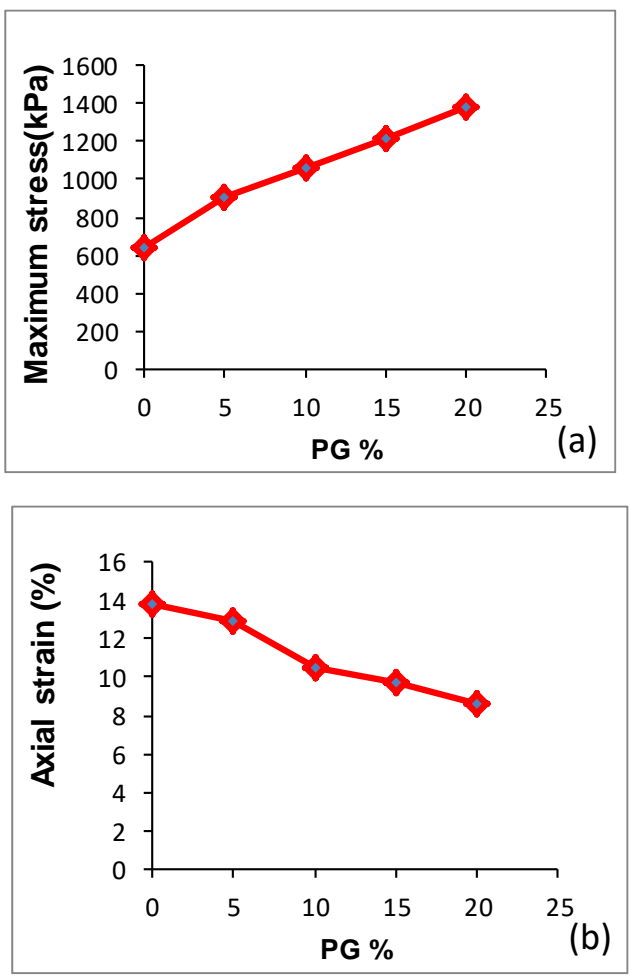

Fig. 5. Unconfined compressive strength (a) and strain (b) of soil stabilized with addition of CPG.

Fig. 6. The effects of different CPG content increase in (a) CBR values, (b) percent swell CBR

\section{CONCLUSION}

In this study, the geotechnical effects of phosphosypsum additive blended granular soils are investigated and the following results are obtained: 
- Experimental results showed that, with the addition of phosphosypsum additive, the maximum dry density of the mixtures decreased and the optimum moisture content increased.

- Additive mixtures increased compressive strength. It has played an important role in the development of CBRs of granular soils. Generally, in all mixtures, the compression strength and CBR values are increased by the addition of CPG additive. Maximum compressive strength and CBR values are obtained by adding $20 \%$ of additive mixtures.

In addition, waste materials, such as phosphosypsum, can potentially reduce the costs of balancing by using waste in a cost-effective manner. In addition, the use of various industrial wastes such as phosphosypsum not only solve the environmental problems but also provides a new source for the construction industry.

\section{REFERENCES}

[1] Degirmenci N., Okucu A. and Turabi Ayse., Application of phosphogypsum in soil stabilization, Building and Environment, 42 (2007) 3393-3398.

[2] Singh M., Influence of blended gypsum on the properties of Portland cement and Portland slag cement, Cement and Concrete Research, 30 (2000) 1185-8.

[3] Altun IA. and Sert Y., Utilization of weathered phosphogypsum as set retarder in Portland cement, Cement and Concrete Research, 34 (2004) 677-80.

[4] Singh M., Treating waste phosphogypsum for cement and plaster manufacture, Cement and Concrete Research, 32 (2002) 1033-8.

[5] Kumar S., A perspective study on the fly ashlime-gypsum bricks and hollow blocks for cost housing development, Construction and Building Materials, 16 (2002) 519-25.

[6] Kumar S., Fly ash-lime-phosphogypsum hollow blocks for walls and partitions, Building and Environment, 38 (2003) 291-5.

[7] Singh M. and Garg M., Cementitious binder from fly ash and other industrial wastes. Cement and Concrete Research, 29 (1999) 309-14.

[8] Verbeek CJR. and du Plessis BJGW., Density and flexural strength of phosphogypsumpolymer composites, Construction and Building Materials, 19 (2005) 265-74.

[9] Gregory CA., Saylak D. and Ledbetter WB., The use by-product of phosphogypsum for road bases and subbases, Transportation Research Board, Washington, DC, (1984) 998.

[10] Chang WF., A demonstration project: roller compacted concrete utilizing phosphogypsum, Florida Institute for Phosphate Research Bartow, FL., 01 (1988) 068-072

[11] Kolias S., Kasselouri-Rigopoulou V. and Kaarhalios., A., Stabilization of clayey soils with high calcium fly ash and cement, Cement and Concrete Composites, 27 (2005) 301-13.

[12] Roy A., Kalvakoalve R. and Seals RK., Microstructure and phase characteristics of phosphogypsum cement mixtures, Journal of Materials in Civil Engineering, 8 (1998), 1118.

[13] ASTM C 150., Standard specification for Portland cement, Annual book of ASTM, Philadelphia, USA: The American Society for Testing and Materials, 04.01-04.02 (2002) 0102

[14] Rahman AMD., Lateric soil in construction, Building and Environment, 21 (1986) 57-61.

[15] Pericleous MI. and Metcalf JB., Resilient modulus of cement-stabilized phosphogypsum, The Journal of Materials of Civil Engineering, 8 (1996) 7-10.

[16] Federal Highway Administration., User guidelines for waste and byproduct materials, FHWA-RD-97-148, Washington DC. (1997).

[17] Chen, F.H., Foundations on Expansive Soils. Elsevier, (1988).

[18] Steinberg, M., Geomembranes and the Control of Expansive Soils in Construction. McGrayHill, New York, (1998)

[19] Nelson, J.D., Miller, D.J., Expansive Soils: Problems and Practice in Foundation and Pavement Engineering. John Wiley and Sons, Inc., New York, (1992).

[20] Yong, R.N., Ouhadi, V.R., Experimental study on instability of bases on natural and lime/cement-stabilized clayey soils, Applied Clay Science, 35 (2007) 238-249.

[21] Puppala, A.J. and Musenda, C., Effects of fiber 
reinforcement on strength and volüme change in expansive soils, Transportation Research Record,00-716 (2002) 134-140

[22] Akbulut, S., Arasan, S. and Kalkan, E., Modification of clayey soils using scrap tire rubber and synthetic fibers, Applied Clay Science, 38 (2007) 23-32.

[23] Moavenian, M.H. and Yasrobi, S.S., Volume change behavior of compacted clay due to organic liquids as permeant, Applied Clay Science, 39 (2008) 60-71.

[24] Degirmenci, N., The using of waste phosphogypsum and natural gypsum in adobe stabilization, Constr. Build. Mater., 22 (2008) 1220-1224. 